\title{
Lactobacillus rossii sp. nov., isolated from wheat sourdough
}

\author{
Aldo Corsetti, ${ }^{1}$ Luca Settanni, ${ }^{1,2}$ Douwe van Sinderen, ${ }^{2}$ Giovanna E. Felis, ${ }^{3}$ \\ Franco Dellaglio ${ }^{3}$ and Marco Gobbetti ${ }^{4}$
}

Correspondence

Marco Gobbetti

gobbetti@agr.uniba.it
Sourdoughs are considered extremely complex ecosystems where lactic acid bacteria (LAB) represent the prevailing microflora. Typical sourdough $\mathrm{LAB}$, responsible for the acidification of dough, are lactobacilli. They consist of obligately and facultatively heterofermentative and obligately homofermentative species (Hammes \& Vogel, 1995). The dominant Lactobacillus species in Italian wheat sourdoughs have been reported to be Lactobacillus sanfranciscensis, Lactobacillus brevis, Lactobacillus fermentum

Published online ahead of print on 19 July 2004 as DOI 10.1099/ ijs.0.63075-0.

Abbreviations: LAB, lactic acid bacteria; RAPD, randomly amplified polymorphic DNA.

The GenBank/EMBL/DDBJ accession number for the 16S rRNA gene sequence of $L$. rossii $C S 1^{\top}$ is AJ564009.

Figures showing analysis of $L$. rossii species-specific PCR and RAPD patterns are available as supplementary material in IJSEM Online. and Lactobacillus fructivorans, belonging to the obligately heterofermentative group of lactobacilli; Lactobacillus plantarum and Lactobacillus alimentarius, belonging to the facultatively heterofermentative group; and Lactobacillus acidophilus, Lactobacillus delbrueckii subsp. delbrueckii and Lactobacillus farciminis, belonging to the obligately homofermentative lactobacilli (Gobbetti et al., 1994; Corsetti et al., 2001, 2003). Some recently described species such as Lactobacillus spicheri (Meroth et al., 2004), Lactobacillus mindensis (Ehrmann et al., 2003), Lactobacillus frumenti (Müller et al., 2000) and Lactobacillus paralimentarius (Cai et al., 1999) were also isolated from sourdough. In this complex system, the synthesis of bacteriocins and other antimicrobial compounds could regulate the interactions within the starter micro-organisms and between the starter and the contaminant microflora of the sourdough (Corsetti et al., 2004).

During a study on the production of antimicrobial 
substances by sourdough $\mathrm{LAB}$, a bacteriocinogenic strain was isolated that could not be assigned to a hithertoknown species by the API $50 \mathrm{CH}$ system and 16S rRNA gene sequence analysis. A species-specific primer pair was designed on the basis of its 16S rRNA gene and five additional isolates from different Italian wheat sourdoughs were found to show high similarity to this isolate. This study presents phenotypic and genotypic evidence to describe these strains as a novel Lactobacillus species, for which we propose the name Lactobacillus rossii sp. nov.

Strains CS1 ${ }^{\mathrm{T}}$, CR20, CF51, CD76, CI35 and CM17 were isolated from wheat sourdoughs of central Italy. Samples were subjected to serial dilution and plated onto modified de Man-Rogosa-Sharpe medium (mMRS) (maltose and fresh yeast extract were added at 1 and $10 \%$, respectively, and the final $\mathrm{pH}$ was adjusted to 5.6) agar as described by Corsetti et al. (2001). The above strains were routinely grown at $30{ }^{\circ} \mathrm{C}$ for $24 \mathrm{~h}$ and maintained at $-80{ }^{\circ} \mathrm{C}$ in glycerol stocks. The purity of the cultures was checked microscopically and by preparing streak cultures. Reference strains were grown on regular MRS (Difco) or mMRS and incubated at the temperature recommended by the respective strain culture collection. Gram determination was performed by Gram staining (Merck) and Gregersen's KOH method (Gregersen, 1978). Cell morphology was studied with a phase-contrast optical microscope (Leitz Laborlux S). Catalase activity was determined by transferring fresh colonies from mMRS agar to a glass slide and adding $5 \% \mathrm{H}_{2} \mathrm{O}_{2}$. Growth at 15 and $45^{\circ} \mathrm{C}$ was tested in mMRS broth. $\mathrm{CO}_{2}$ production was detected in sourdough bacteria broth (Kline \& Sugihara, 1971) containing glucose in place of maltose and supplemented with $10 \%$ gelatin powder in test tubes sealed with $2 \%$ sterile molten agar. Arginine hydrolysis was determined according to the method of Sharpe (1979). The isomeric type of lactate in fermented broth was determined enzymically using the DL-lactate test kit (Boehringer). A fermentation profile was determined using the API 50 CH System (bioMérieux). The peptidoglycan structure of the cell wall was determined at the DSMZ (Deutsche Sammlung von Mikroorganismen und Zellkulturen, Braunschweig, Germany) by one-dimensional and two-dimensional TLC (Schleifer \& Kandler, 1972) followed by derivatization (MacKenzie, 1987). The approximate molar amino acid ratio was determined by GC as reported by Groth et al. (1996). The $\mathrm{N}$ terminus of the interpeptide bridge was determined as reported by Schleifer (1985). For the preparation of genomic DNA for PCR assays, cells from $2 \mathrm{ml}$ of overnight cultures were harvested and DNA was extracted according to the method of De Los Reyes-Gavilán et al. (1992). The concentration and purity of DNA was assayed by determining $A_{260}$ and $A_{280}$, as described by Sambrook et al. (1989). 16S rRNA gene amplification was performed using the LacbF/LacbR primer pair following the method of Corsetti et al. (2004). PCR products were purified using the Concert Rapid PCR Purification System (Gibco). DNA sequencing reactions were performed by MWG Biotech AG. In order to determine the phylogenetic placement of strain $\mathrm{CS}^{\mathrm{T}}$, the nearly complete 16S rRNA gene sequences of 17 Lactobacillus species, most of them often reported as typical organisms in sourdough fermentation (Vogel et al., 1999; Müller et al., 2000; Corsetti et al., 2003), were aligned using the CLUSTAL W program (Thompson et al., 1994) and phylogenetic analysis was performed with MEGA version 2.1 (Kumar et al., 2001): the distance matrix was obtained with the Kimura two-parameter formula and tree reconstruction with neighbour-joining clustering. An analysis of the robustness of the tree was obtained by bootstrap analysis with 1000 replicates. A second distance-matrix analysis was performed using the program TREECON (van de Peer \& de Wachter, 1994) with the Galtier-Gouy model as the distance formula and neighbour joining as the clustering option. A maximum-parsimony method was also applied with default options as implemented in PHYLIP DNAPARS (Felsenstein, 1993). A maximum-likelihood analysis was performed with the DNAML program in the PHYLIP software package (Felsenstein, 1993). The G $+\mathrm{C}$ content of the DNA (mol\%) of strain $\mathrm{CS}^{\mathrm{T}}$ was determined at the DSMZ by an HPLC analytical method. DNA was isolated and purified by chromatography on hydroxyapatite according to the procedure of Cashion et al. (1977) and was hydrolysed and dephosphorylated as reported by Mesbah et al. (1989). HPLC was carried out using the protocol described by Tamaoka \& Komagata (1984). Wild-type phage lambda DNA was used as the standard (Mesbah et al., 1989). The $\mathrm{G}+\mathrm{C}$ content was determined according to the method of Mesbah et al. (1989). Since a $93 \%$ identity value for $16 \mathrm{~S}$ rRNA gene sequences is rather low, determination of DNA homology values was performed by the DSMZ between strain $\mathrm{CS}^{\mathrm{T}}$ and the type strain of one of its closest phylogenetic relatives, Lactobacillus durianis. DNA was isolated and purified as for DNA base composition analysis. DNA-DNA hybridization was carried out as described by De Ley et al. (1970), with the modifications described by Huss et al. (1983) and Escara \& Hutton (1980), using a model 2600 spectrophotometer equipped with a model 2527-R thermoprogrammer and plotter (Gilford Instrument Laboratories). Renaturation rates were computed with the TRANSFER.BAS program of Jahnke (1992). Primers for the species-specific PCR assay were designed on regions of high sequence heterogeneity in the 16S rRNA gene sequence alignment of lactobacilli included in the phylogenetic tree (see Fig. 1 for corresponding accession numbers) plus another 19 Lactobacillus species (GenBank/EMBL/DDBJ accession nos M58811, M58821, D86517, D16551, AY204893, AY204892, AY204894, AF089108, X94229, AF243177, X76328, M58805, Y17362, M58802, Y17361, M58814, AJ002515, AJ306297 and D79211). The primers used were LrosF ( $5^{\prime}$-GTATCTGAGAGTAACTGTTCAGA$\left.3^{\prime}\right)$ and LrosR (5'-AGGGAACGTCCGATCTCTCG-3') and PCR was performed using the same reaction volume and reaction mixture composition as described for amplification with the LacbF/LacbR primer pair (Corsetti et al., 2004). The PCR programme comprised an initial template denaturation step for $4 \mathrm{~min}$ at $94^{\circ} \mathrm{C}$ followed by 30 cycles 


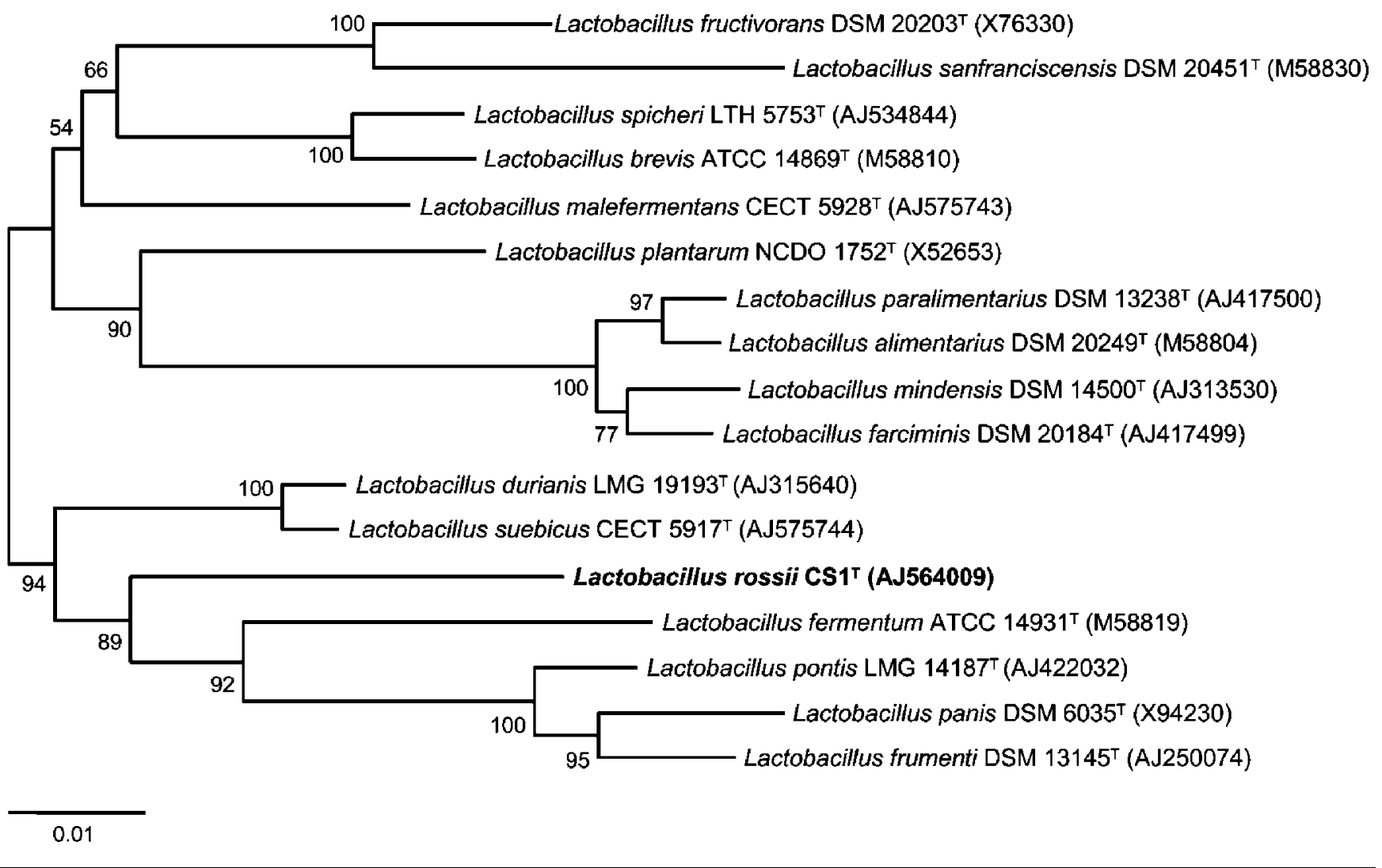

Fig. 1. Phylogenetic tree showing the relationships between $L$. rossii $C S 1^{\top}$ and several related Lactobacillus species on the basis of $16 \mathrm{~S}$ rRNA gene sequences. The tree was created by aligning $1360 \mathrm{nt}$. Bar, $0 \cdot 01$ nucleotide substitution per site.

of denaturation for $45 \mathrm{~s}$ at $94^{\circ} \mathrm{C}$, annealing for $30 \mathrm{~s}$ at $58^{\circ} \mathrm{C}$ and extension for $45 \mathrm{~s}$ at $72^{\circ} \mathrm{C}$. The final extension step was for $7 \mathrm{~min}$ at $72^{\circ} \mathrm{C}$. To exclude clonal relatedness, four oligonucleotides, P1 (5'-ACGCGCCCT-3'), P4 (5'-CCGCAGCGTT-3'), P7 (5'-AGCAGCGTGG-3') (Corsetti et al., 2003) and M13 (5'-GAGGGTGGCGGTTCT-3') (Stendid et al., 1994), with arbitrarily chosen sequences, were used to examine the six $L$. rossii strains by randomly amplified polymorphic DNA (RAPD)-PCR. DNA amplification was carried out in $30 \mu \mathrm{l} \mathrm{PCR}$ mixture containing $12 \mu \mathrm{l}$ Taq PCR Master Mix, 1 pmol primer, $1 \mu$ l template DNA ( $\sim 25 \mathrm{ng}$ DNA) and sterile distilled $\mathrm{H}_{2} \mathrm{O}$. The PCR programme reported by Corsetti et al. (2003) was used for primers P1, P4 and P7, whereas that reported by Zapparoli et al. (1998) was used for primer M13.

Colonies of L. rossii $\mathrm{CS}^{\mathrm{T}}$ grown on mMRS agar at $30{ }^{\circ} \mathrm{C}$ for 3 days were $1-1.5 \mathrm{~mm}$ in diameter, white, smooth and circular when they were grown on the surface of the agar medium. If colonies were within the agar medium the appearance changed to a convex shape. Cells were rods of approximately $0.5 \times 1-1.5 \mu \mathrm{m}$, non-motile, non-sporeforming and occurring singly, in pairs and in short chains. All isolates stained Gram-positive and were negative for the catalase assay. Physiological and biochemical characteristics, as well as the sugar fermentation pattern of $L$. rossii strains and the reference $\mathrm{LAB}$, are listed in Table 1 . All $L$. rossii strains produced DL-lactate (the $\mathrm{D}$ isomer comprised $50 \pm 5 \%$ of the total amount of lactic acid produced) and $\mathrm{CO}_{2}$ from glucose, thus being obligately heterofermentative. Obligate heterofermentative species such as L. sanfranciscensis, L. brevis, L. fermentum and L. fructivorans are typically found in wheat-flour Italian sourdoughs (Gobbetti et al., 1994; Corsetti et al., 2001, 2003), as well as in traditional three-stage-processed doughs (Stolz, 1995), and for that reason they were chosen as reference organisms (Table 1). The peptidoglycan structure was of the A3 $\alpha$ (L-Lys-L-Ser-L$\mathrm{Ala}_{2}$ ) type. Among Lactobacillus species this peptidoglycan type is only shown by Weissella minor (Hammes \& Vogel, 1995), formerly 'Lactobacillus minor' (Kandler et al., 1983; Collins et al., 1993). The highest similarity value of strain $\mathrm{CS}^{\mathrm{T}}$, i.e. $93 \%$, was found with a recently described species, L. durianis (Leisner et al., 2002), and with Lactobacillus malefermentans and Lactobacillus suebicus, while similarities of $92 \%$ or lower were found with other species of the genus Lactobacillus. This clearly indicated that strain $\mathrm{CS}^{\mathrm{T}}$ could represent a novel species since the similarity value was less than $97 \%$ with the closest relative (Stackebrandt \& Goebel, 1994). The resulting tree is shown in Fig. 1. Strain $\mathrm{CS}^{\mathrm{T}}$ had a G $+\mathrm{C}$ content of $44 \cdot 6 \mathrm{~mol} \%$. This value is within the range for the genus Lactobacillus (32-53 mol\%) (Kandler \& Weiss, 1986). The DNA-DNA homology value 
Table 1. Phenotypic characteristics of the strains of L. rossii, the closest related species and sourdough-associated species of Lactobacillus

-, Negative reaction; +, positive reaction; W, weak response; ND, not determined. $1, L$. rossii $\mathrm{CS}^{\mathrm{T}}$; 2 , other $L$. rossii isolates $(n=5)$; 3 , $L$. durianis LMG $19193^{\mathrm{T}}$ (data from Leisner et al., 2002); 4, L. malefermentans NCDO $1410^{\mathrm{T}}$ (Farrow et al., 1986); 5, L. suebicus DSM 5007 (Kleynmans et al., 1989). The following data were from Hammes \& Vogel (1995) and Kandler \& Weiss (1986); these authors use the following symbols:,$+>90 \%$ of strains are positive;,$->90 \%$ of strains are negative; d, $11-89 \%$ of strains are positive; 6, L. sanfranciscensis; 7, L. fructivorans; 8, L. brevis; 9, L. fermentum. Details of the variable fermentations of L. rossii strains: galactose and gluconate were fermented by strain CR20 and CM17 and only weakly by the other strains. D-Mannose was fermented by strain CD76, whereas weak positive reactions were detected for the other strains; CR20 produced acid from melibiose but was weakly fermented by strains CI35 and CF51. D-Xylose was fermented only by strains $\mathrm{CS}^{\mathrm{T}}$ and CD76, and D-lyxose was fermented by all strains except strain $\mathrm{CS1}^{\mathrm{T}}$.

\begin{tabular}{|c|c|c|c|c|c|c|c|c|c|}
\hline Characteristic & 1 & 2 & 3 & 4 & 5 & 6 & 7 & 8 & 9 \\
\hline \multicolumn{10}{|l|}{ Growth at: } \\
\hline $15^{\circ} \mathrm{C}$ & + & + & + & + & + & + & + & + & - \\
\hline $45^{\circ} \mathrm{C}$ & - & - & - & - & - & - & - & - & + \\
\hline \multicolumn{10}{|l|}{ Production of: } \\
\hline $\mathrm{CO}_{2}$ from glucose & + & + & $-{ }^{*}$ & + & + & + & + & + & + \\
\hline $\mathrm{NH}_{3}$ from arginine & + & + & - & + & ND & - & + & + & + \\
\hline Aesculin hydrolysis & - & - & + & - & - & ND & - & $\mathrm{d}$ & - \\
\hline Isomeric type of lactate & DL & DL & DL & ND & DL & ND & ND & ND & DL \\
\hline \multicolumn{10}{|l|}{ Acid production from: } \\
\hline L-Arabinose & + & + & + & - & + & - & - & + & $\mathrm{d}$ \\
\hline Ribose & + & + & + & + & + & $\mathrm{d}$ & $\mathrm{W}$ & + & + \\
\hline D-Xylose & + & $+1-$ & + & - & + & - & - & $\mathrm{d}$ & $\mathrm{d}$ \\
\hline Galactose & $\mathrm{W}$ & $+/ \mathrm{w}$ & + & - & + & $\mathrm{d}$ & - & d & + \\
\hline D-Glucose & + & + & + & + & + & + & + & + & + \\
\hline D-Fructose & + & + & - & - & - & - & + & + & + \\
\hline D-Mannose & $\mathrm{W}$ & $+/ \mathrm{w}$ & - & - & - & - & - & - & $\mathrm{w}$ \\
\hline$N$-Acetylglucosamine & + & + & - & + & - & ND & ND & ND & ND \\
\hline Maltose & + & + & + & + & + & + & $\mathrm{d}$ & + & + \\
\hline Melibiose & - & $+/ \mathrm{w} /-$ & - & - & + & - & - & + & + \\
\hline D-Lyxose & - & + & + & - & - & ND & ND & ND & ND \\
\hline Gluconate & $\mathrm{W}$ & $+/ \mathrm{w}$ & $\mathrm{W}$ & + & - & $\mathrm{ND}$ & ND & ND & ND \\
\hline Peptidoglycan type & L-Lys-L-Ser-L-Ala 2 & ND & ND & ND & $m$-Dpm & L-Lys-Ala & L-Lys-D-Asp & L-Lys-D-Asp & L-Orn-D-Asp \\
\hline DNA G $+\mathrm{C}$ content $(\mathrm{mol} \%)$ & $44 \cdot 6$ & ND & $43 \cdot 2-43 \cdot 3$ & $41-42$ & $40-40 \cdot 7$ & $36-38$ & $38-41$ & $44-47$ & $52-54$ \\
\hline
\end{tabular}

${ }^{\star}$ Gas is produced from gluconic acid but not from glucose.

between L. rossii $\mathrm{CS}^{\mathrm{T}}$ and L. durianis $\mathrm{LMG} 19193^{\mathrm{T}}$ was $34 \cdot 3 \%$, thus demonstrating that strain $\mathrm{CS}^{\mathrm{T}}$ represents a novel species of the genus Lactobacillus. The specificity of the LrosF/LrosR primer pair was checked against the closest related species (L. durianis, L. malefermentans and L. suebicus), the species showing a high similarity of $16 \mathrm{~S}$ rRNA gene sequences in the regions of primer annealing (Lactobacillus buchneri, L. delbrueckii subsp. delbrueckii, L. fermentum, Lactobacillus casei, Lactobacillus pentosus and $L$. plantarum) and some of the typical sourdoughassociated species (L. alimentarius, L. brevis, L. farciminis, $L$. frumenti, Lactobacillus panis, Lactobacillus pontis and $L$. sanfranciscensis). A group of strains isolated from several sourdoughs (Corsetti et al., 2004) and showing $\mathrm{CS}^{\mathrm{T}}$-like phenotypic characteristics was screened with this speciesspecific PCR assay and the $575 \mathrm{bp}$ DNA amplification product was obtained from strain $\mathrm{CS}^{\mathrm{T}}$ and isolates CR20, CF51, CD76, CI35 and CM17 when specific primers were used, while no amplification product was obtained from the other species of Lactobacillus used as negative controls. Accessibility of DNA for amplification assays was ensured by a control PCR using primers LacbF and LacbR, designed to amplify a fragment of approximately $1370 \mathrm{bp}$ from the 16S rRNA gene within the genus Lactobacillus. PCR amplification products, except for $L$. malefermentans and $L$. suebicus, are shown in Fig. A, available as supplementary material in IJSEM Online. Under the conditions used, primers LrosF and LrosR were selective for $L$. rossii strains. However, for further confirmation, $16 \mathrm{~S}$ rRNA gene sequence analysis was performed and $100 \%$ identity among the six sequences was found. RAPD-PCR is a PCR-based method used to evaluate microbial biodiversity and provides a reliable way of discriminating strains belonging to the same species (Vincent et al., 1998). RAPD-PCR analysis was successfully used to differentiate $L$. plantarum (Johansson et al., 1995) and L. sanfranciscensis (Zapparoli 
et al., 1998) at the intraspecies level. RAPD patterns obtained with the four primers for the six strains of $L$. rossii are shown in Fig. B, available as supplementary material in IJSEM Online. Even though RAPD-PCR using all four oligonucleotides as primers generated only a small number of DNA fragments, they were able to provide evidence of DNA polymorphisms among the strains tested. All four primers could distinguish strain $\mathrm{CS}^{\mathrm{T}}$ from strain CD76, and these two strains from the other L. rossii strains. Primer $\mathrm{P} 4$ could distinguish strain $\mathrm{CI} 35$ from strains CR20, CF51 and CM17. However, in addition to RAPD patterns, different biochemical features of strains CR20, CF51 and CM17, besides their different geographical origin, clearly allowed strain differentiation, thus excluding clonal relatedness.

On the basis of the results shown in this study, we propose that strain $\mathrm{CS}^{\mathrm{T}}$ is classified as a novel species and that strains CR20, CF51, CD76, CI35 and CM17 are placed in the following novel species of the genus Lactobacillus: Lactobacillus rossii sp. nov.

\section{Description of Lactobacillus rossii sp. nov.}

Lactobacillus rossii (ros.si'i. N.L. gen. n. rossii of Rossi, to honour Professor Jone Rossi, University of Perugia, Perugia, Italy, for her main contribution to dairy and sourdough microbiology).

Cells are Gram-positive rods of approximately $0.5 \times 1-$ $1.5 \mu \mathrm{m}$. Non-motile, non-spore-forming and occur singly, in pairs and in short chains. After growth for 3 days at $30{ }^{\circ} \mathrm{C}$ on mMRS agar plates, colonies are $1-1.5 \mathrm{~mm}$ in diameter, white, smooth and circular or convex. Microaerophilic. Catalase-negative. Growth is observed at 15 but not at $45^{\circ} \mathrm{C}$. Obligately heterofermentative. Ammonia is produced from arginine. Aesculin is not hydrolysed. Both D- and L-lactic acid are produced. Acid is produced from L-arabinose, ribose, D-glucose, D-fructose, $\mathrm{N}$-acetylglucosamine and maltose. The majority of strains also ferment D-lyxose and weakly ferment galactose, D-mannose and gluconate. Some strains are able to ferment D-xylose and melibiose. Glycerol, erythritol, D-arabinose, L-xylose, adonitol, methyl $\beta$-xyloside, L-sorbose, rhamnose, dulcitol, inositol, mannitol, sorbitol, methyl $\alpha$-D-mannoside, methyl $\alpha$-D-glucoside, amygdalin, arbutin, salicin, cellobiose, lactose, sucrose, trehalose, inulin, melezitose, D-raffinose, amidon, glycogen, xylitol, $\beta$-gentibiose, D-turanose, $\mathrm{D}$ tagatose, D- and L-fucose, D- and L-arabitol, and 2- and 5-ketogluconate are not fermented. Peptidoglycan structure is $\mathrm{A} 3 \alpha$ (L-Lys-L-Ser-L-Ala $)$ type. The DNA G $+\mathrm{C}$ content is $44.6 \mathrm{~mol} \%$. Isolated from wheat sourdough.

The type strain is $\operatorname{CS}^{\mathrm{T}}\left(=\right.$ ATCC BAA $-822^{\mathrm{T}}=$ DSM $\left.15814^{\mathrm{T}}\right)$.

\section{References}

Cai, Y., Okada, H., Mori, H., Benno, Y. \& Nakase, T. (1999). Lactobacillus paralimentarius sp. nov., isolated from sourdough. Int J Syst Bacteriol 49, 1451-1455.
Cashion, P., Holder-Franklin, M. A., McCully, J. \& Franklin, M. (1977). A rapid method for the base ratio determination of bacterial DNA. Anal Biochem 81, 461-466.

Collins, M. D., Samelis, J., Metaxopoulos, J. \& Wallbanks, S. (1993). Taxonomic studies on some Leuconostoc-like organisms from fermented sausages: description of a new genus Weissella for the Leuconostoc paramesenteroides group of species. J Appl Bacteriol 75, 595-603.

Corsetti, A., Lavermicocca, P., Morea, M., Baruzzi, F., Tosti, N. \& Gobbetti, M. (2001). Phenotypic and molecular identification and clustering of lactic acid bacteria and yeasts from wheat (species Triticum durum and Triticum aestivum) sourdoughs of Southern Italy. Int J Food Microbiol 64, 95-104.

Corsetti, A., De Angelis, M., Dellaglio, F., Paparella, A., Fox, P. F., Settanni, L. \& Gobbetti, M. (2003). Characterization of sourdough lactic acid bacteria based on genotypic and cell-wall protein analyses. J Appl Microbiol 94, 641-654.

Corsetti, A., Settanni, L. \& van Sinderen, D. (2004). Characterization of bacteriocin-like inhibitory substances (BLIS) from sourdough lactic acid bacteria and evaluation of their in vitro and in situ activity. J Appl Microbiol 96, 521-534.

De Ley, J., Cattoir, H. \& Reynaerts, A. (1970). The quantitative measurement of DNA hybridization from renaturation rates. Eur J Biochem 12, 133-142.

De Los Reyes-Gavilán, C. G., Limsowtin, G. K. Y., Tailliez, P., Séchaud, L. \& Accolas, J. P. (1992). A Lactobacillus helveticusspecific DNA probe detects restriction fragment length polymorphisms in this species. Appl Environ Microbiol 58, 3429-3432.

Ehrmann, M. A., Muller, M. R. \& Vogel, R. F. (2003). Molecular analysis of sourdough reveals Lactobacillus mindensis sp. nov. Int J Syst Evol Microbiol 53, 7-13.

Escara, J. F. \& Hutton, J. R. (1980). Thermal stability and renaturation of DNA in dimethyl sulfoxide solutions: acceleration of renaturation rate. Biopolymers 19, 1315-1327.

Farrow, J. A. E., Phillips, B. A. \& Collins, M. D. (1986). Nucleic acid studies on some heterofermentative lactobacilli: description of Lactobacillus malefermentans sp. nov. and Lactobacillus parabuchneri sp. nov. FEMS Microbiol Lett 55, 163-168.

Felsenstein, J. (1993). PHYLIP (Phylogeny Inference Package) version 3.5c. Distributed by the author. Department of Genetics, University of Washington, Seattle, WA, USA.

Gobbetti, M., Corsetti, A., Rossi, J., La Rosa, F. \& De Vincenzi, S. (1994). Identification and clustering of lactic acid bacteria and yeasts from wheat sourdoughs of central Italy. Ital J Food Sci 1, 85-94.

Gregersen, T. (1978). Rapid method for distinction of Gramnegative from Gram-positive bacteria. Eur J Appl Microbiol Biotechnol 5, 123-127.

Groth, I., Schumann, P., Weiss, N., Martin, K. \& Rainey, F. A. (1996). Agrococcus jenensis gen. nov., sp. nov., a new genus of actinomycetes with diaminobutyric acid in the cell wall. Int $J$ Syst Bacteriol 46, 234-239.

Hammes, W. P. \& Vogel, R. F. (1995). The genus Lactobacillus. In The Lactic Acid Bacteria, vol. 2, The Genera of Lactic Acid Bacteria, pp. 19-54. Edited by B. J. B. Wood \& W. H. Holzapfel. London: Blackie Academic \& Professional.

Huss, V. A. R., Festl, H. \& Schleifer, K. H. (1983). Studies on the spectrophotometric determination of DNA hybridization from renaturation rates. Syst Appl Microbiol 4, 184-192.

Jahnke, K. D. (1992). Basic computer program for evaluation of spectroscopic DNA renaturation data from GILFORD System 2600 spectrometer on a PC/XT/AT type personal computer. J Microbiol Methods 15, 61-73. 
Johansson, M. L., Quednau, M., Molin, G. \& Ahrné, S. (1995). Randomly amplified polymorphic DNA (RAPD) for rapid typing of Lactobacillus plantarum strains. Lett Appl Microbiol 21, 155-159.

Kandler, O. \& Weiss, N. (1986). Genus Lactobacillus Beijerinck 1901. In Bergey's Manual of Systematic Bacteriology, vol. 2, pp. 1209-1234. Edited by P. H. A. Sneath, N. S. Mair, M. E. Sharpe \& J. G. Holt. Baltimore: Williams \& Wilkins.

Kandler, O., Schillinger, U. \& Weiss, N. (1983). Lactobacillus halotolerans sp. nov., nom. rev. and Lactobacillus minor sp. nov., nom. rev. Syst Appl Microbiol 4, 280-285.

Kleynmans, U., Heinzl, H. \& Hammes, W. P. (1989). Lactobacillus suebicus sp. nov., an obligately heterofermentative Lactobacillus species isolated from fruit mashes. Syst Appl Microbiol 11, 267-271.

Kline, L. \& Sugihara, T. F. (1971). Microorganisms of the San Francisco sour dough bread process. II. Isolation and characterization of undescribed bacterial species responsible for the souring activity. Appl Microbiol 21, 459-465.

Kumar, S., Tamura, K., Jakobsen, I. B. \& Nei, M. (2001). MEGA2: molecular evolutionary genetics analysis software. Bioinformatics 17, 1244-1245.

Leisner, J. J., Vancanneyt, M., Lefebvre, K., Vandemeulebroecke, K., Hoste, B., Vilalta, N. E., Rusul, G. \& Swings, J. (2002). Lactobacillus durianis sp. nov., isolated from an acid-fermented condiment (tempoyak) in Malaysia. Int J Syst Evol Microbiol 52, 927-931.

MacKenzie, S. L. (1987). Gas chromatographic analysis of amino acids as the $\mathrm{N}$-heptafluorobutyryl isobutyl esters. J Assoc Anal Chem 70, 151-160.

Meroth, C. B., Hammes, W. P. \& Hertel, C. (2004). Characterisation of the microbiota of rice sourdoughs and description of Lactobacillus spicheri sp. nov. Syst Appl Microbiol 27, 151-159.

Mesbah, M., Premachandran, U. \& Whitmann, W. (1989). Precise measurement of the $\mathrm{G}+\mathrm{C}$ content of deoxyribonucleic acid by high performance liquid chromatography. Int J Syst Bacteriol 39, 159-167.

Müller, M. R. A., Ehrmann, M. A. \& Vogel, R. F. (2000). Lactobacillus frumenti sp. nov., a new lactic acid bacterium isolated from rye-bran fermentations with a long fermentation period. Int J Syst Evol Microbiol 50, 2127-2133.
Sambrook, J., Fritsch, E. F. \& Maniatis, T. (1989). Molecular Cloning: a Laboratory Manual, 2nd edn. Cold Spring Harbor, NY: Cold Spring Harbor Laboratory.

Schleifer, K. H. (1985). Analysis of the chemical composition and primary structure of murein. Methods Microbiol 18, 123-156.

Schleifer, K. H. \& Kandler, O. (1972). Peptidoglycan types of bacterial cell walls and their taxonomic implications. Bacteriol Rev 36, 407-477.

Sharpe, M. E. (1979). Identification of lactic acid bacteria. In Identification Methods for Microbiologists (Technical Series 14), pp. 233-259. Edited by F. A. Skinner \& D. W. Lovelock. London: Academic Press.

Stackebrandt, E. \& Goebel, B. M. (1994). Taxonomic note: a place for DNA-DNA reassociation and $16 \mathrm{~S}$ rRNA sequence analysis in the present species definition in bacteriology. Int J Syst Bacteriol 44, 435-439.

Stendid, J., Karlsson, J. O. \& Hogberg, N. (1994). Intra-specific genetic variation in Heterobasidium annosum revealed by amplification of minisatellite DNA. Mycol Res 98, 57-63.

Stolz, P. (1995). Untersuchungen des Maltosemetabolismus von Lactobazillen aus Sauerteig. Stuttgart: Ulrich Grauer.

Tamaoka, J. \& Komagata, K. (1984). Determination of DNA base composition by reversed-phase high performance liquid chromatography. FEMS Microbiol Lett 25, 125-128.

Thompson, J. D., Higgins, D. G. \& Gibson, T. J. (1994). CLUSTAL W: improving the sensitivity of progressive multiple sequence alignment through sequence weighting, position-specific gap penalties and weight matrix choice. Nucleic Acids Res 22, 4673-4680.

van de Peer, Y. \& de Wachter, R. (1994). TREECON for Windows: a software package for the construction and drawing of evolutionary trees for the Microsoft Windows environment. Comput Appl Biosci 10, 569-570.

Vincent, D., Roy, D., Mondou, F. \& Déry, C. (1998). Characterization of bifidobacteria by random DNA amplification. Int J Food Microbiol 43, 185-193.

Vogel, R. F., Knorr, R., Müller, R. A., Steudel, U., Gänzle, M. G. \& Ehrmann, M. A. (1999). Non-dairy lactic fermentations: the cereal world. Antonie van Leeuwenhoek 76, 403-411.

Zapparoli, G., Torriani, S. \& Dellaglio, F. (1998). Differentiation of Lactobacillus sanfranciscensis strains by randomly amplified polymorphic DNA and pulsed-field gel electrophoresis. FEMS Microbiol Lett 166, 324-332. 